\title{
Selecting SUDS in the Valencia Region of Spain
}

\author{
A. Casal-Campos ${ }^{1}$, C. Jefferies ${ }^{1 *}$ and S. Perales Momparler ${ }^{2}$ \\ ${ }^{1}$ University of Abertay Dundee, Urban Water Technology Centre, Level 5 Kydd Building, \\ Bell Street, Dundee DD1 1HG, Scotland. \\ ${ }^{2}$ PMEnginyeria, Avda. Aragón, 18-1-1, 46021, Valencia, Spain. \\ *Corresponding Author: c.jefferies@abertay.ac.uk
}

\begin{abstract}
This paper reports on a study of the implementation of sustainable urban drainage systems (SUDS) in two Spanish towns (Xàtiva and Benaguasil) as part of the EU LIFE+ Project AQUAVAL, which has been conceived to introduce examples of sustainable drainage to the Valencia Region of Spain. Six sites in a range of common urban spaces and land uses are selected and appropriate SUDS techniques proposed by means of a decision-support process. This primarily consisted of the systematic application of key selection criteria through matrices and scores, followed by a brief sustainability analysis. Stakeholders' preferences and opinions as well as educational and social opportunities are highly considered throughout the process. General monitoring requirements and major limitations in using the methodology are outlined, stressing the need for improvement of four main aspects: local data regarding SUDS performance, detail of the sustainability analysis, support through comprehensive modelling tools, and level of stakeholder engagement. The importance of creating showcases for SUDS in Mediterranean Regions, thus adapting key selection criteria as to foster sustainable drainage understanding and expertise is highlighted.
\end{abstract}

\section{KEYWORDS}

Mediterranean Regions, Spain, Stormwater Management, SUDS, Sustainable Drainage.

\section{INTRODUCTION}

\section{CSOs and European Community legislation}

The EU Water Framework Directive addresses the condition of European ground, surface, transitional and coastal waters; requiring actions to be taken to ensure good ecological and chemical status of community waters by 2015 . However, in spite of the many improvements and advantages brought by the Directive, the extensive use of combined sewers in urban areas throughout Europe still poses problems (i.e. CSO spills) which bring additional difficulties as to meet environmental objectives. Further, other communitarian regulations, such as the EU Urban Waste Water Treatment Directive, have stressed the need to improve these discharges as to reduce urban water impairment (Lau et al. 2002).

\section{Drainage in Spain}

In Spain, the incorporation of European water legislation has been partially constrained by a lack of permits for and monitoring of combined sewer overflows (CSOs) (Zabel et al. 2001) although there are exceptions such as the PROMEDSU pilot project, (Ministerio de Medio Ambiente 2002). Monitoring would have allowed the control of intermittent discharges to watercourses under wet-weather conditions and evaluation of their impacts to a greater extent. 
Surface water drainage in dry areas of Spain has been traditionally overlooked and considered a secondary component of combined sewers, rarely relevant except during periods of torrential rainfall. This attitude, along with rain patterns which greatly differ from those in countries where the principles of sustainable drainage have been widely implemented, might partially explain the superficial imprint of sustainable urban drainage systems (SUDS) in Spain (Deutsch et al. 2003).

The introduction of SUDS techniques in Spain is not new and applications can be found in major cities, such as the Master Drainage Plan of Barcelona and the good practices used in Madrid (Ayuntamiento de Madrid 2009). Further, there is lively interest in developing expertise and guidance, particularly from academics in the Universities of Corunna (PuertasAgudo et al. 2008) and Cantabria (Castro-Fresno et al. 2009, Castro-Fresno et al. 2005).

\section{The AQUAVAL Project}

The EU LIFE+ Project AQUAVAL commenced in January 2010 to introduce examples of stormwater quantity and quality controls to the Valencia Region. The project has the objective of constructing examples of sustainable urban drainage systems (SUDS) within two communities in the Valencia Region, monitoring their performance and producing local guidance for SUDS which might also be applicable in other Mediterranean Regions.

Through the construction of local demonstration sites, AQUAVAL aims to develop innovative sustainable solutions to the drainage problems which will improve stormwater management and bring benefits beyond the Valencia Region, providing a showcase for Southern European Regions in the development of a sustainable drainage culture.

\section{DECISION-SUPPORT PROCESS}

The decision-support process used to select appropriate SUDS techniques is based principally on that of the CIRIA SUDS Manual (CIRIA 2007) adapted to the conditions of the study area. Although the process is designed to incorporate stakeholders' opinions and preferences, the drainage tool has been primarily conceived as a technical tool to be used by drainage practitioners and academics. The sequence of stages and criteria used are shown in Figure 1.

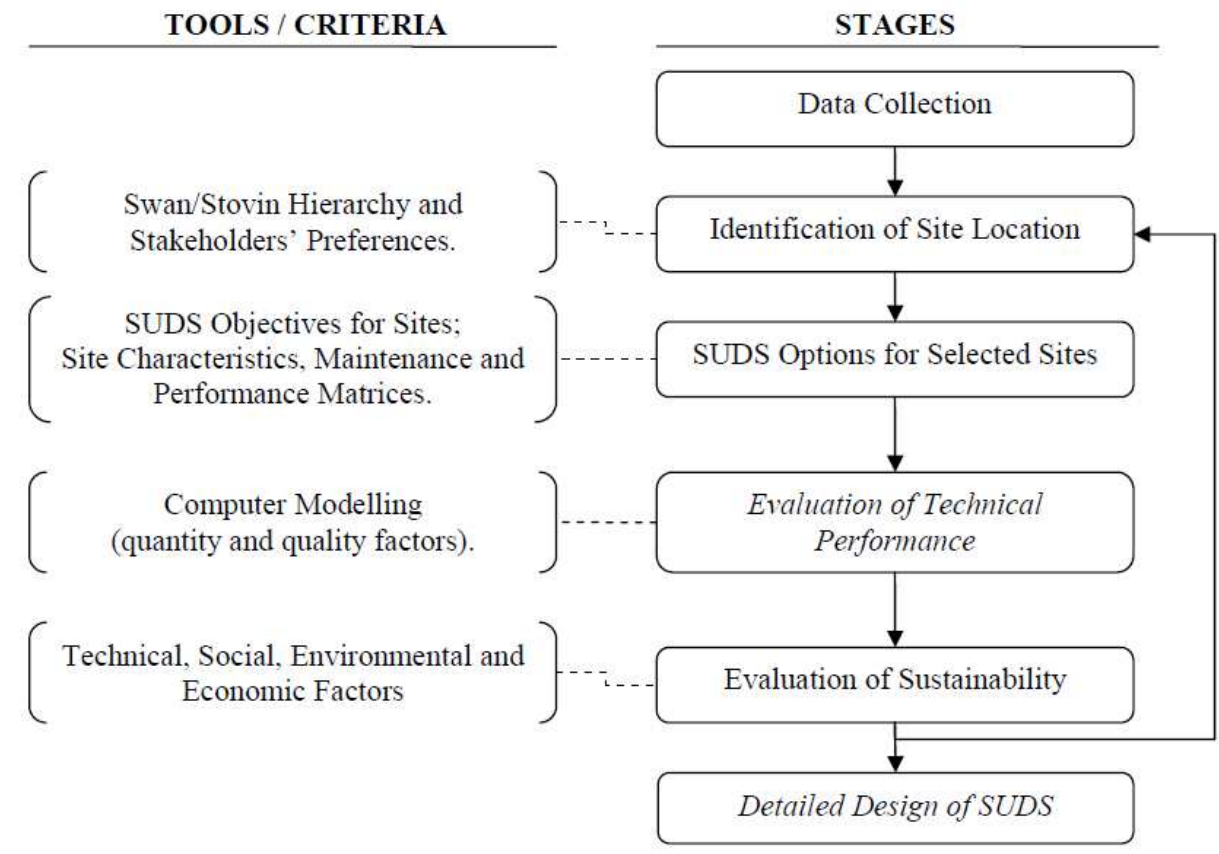


Figure 1. Decision-support process adopted and relevant criteria involved. Stages in italics were not considered for the purposes of this paper.

\section{Identification of site locations}

Sites for SUDS were identified by application of the Swan/Stovin hierarchy, stressing on the use of institutional facilities and areas where source control and infiltration systems would provide simple and effective solutions. In addition to this, drainage objectives and other drivers brought by stakeholders were incorporated at this stage as to consider sites which might be underestimated by the hierarchy (e.g. opportunities to improve drainage planning in urban areas under development, areas which may enhance educational or social value).

\section{SUDS options for selected sites}

Alternatives were initially screened using the criteria in Table 1 and ranked using their social and educational potential (e.g. visible/dual-purpose techniques, rainwater re-use), and/or stakeholder's preferences (e.g. opportunistic solutions that integrate in already planned sites). The options were then ranked using adapted O\&M scores (see Table 2; adapted scores reduced the frequency of rainfall-related tasks, such as sediment removal or filter media rehabilitation; increasing litter and debris removal requirements), weighed according to their likely frequency of use in the area.

Their technical performance was estimated adding quantity and quality performance scores of Table 3 (typical performance scores for the UK provided some guidance due to the lack of local relevant data). Finally, the mentioned ranks were added as to obtain a global score, selecting the lowest score as preferred option (see
Table 1: Site Characteristics Matrix.

\begin{tabular}{|c|c|c|c|c|c|c|c|c|c|c|c|c|c|}
\hline \multirow[b]{2}{*}{ SUDS Technique } & \multicolumn{2}{|c|}{$\begin{array}{l}\text { Land } \\
\text { Req. }\end{array}$} & \multicolumn{2}{|c|}{$\begin{array}{l}\text { Ground } \\
\text { Constrain }\end{array}$} & \multirow{2}{*}{ 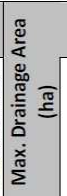 } & \multicolumn{8}{|c|}{ Suitable Land Uses } \\
\hline & 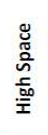 & 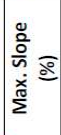 & 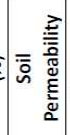 & 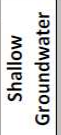 & & 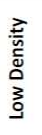 & 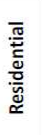 & 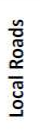 & 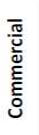 & 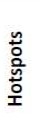 & 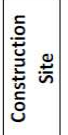 & 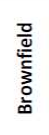 & 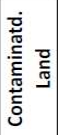 \\
\hline Greenroof & NA & $>5$ & NA & $\mathrm{Y}$ & 2 & $\mathrm{Y}$ & $Y$ & $\mathrm{~N}$ & $\mathrm{Y}$ & $\mathrm{Y}$ & $\mathrm{N}$ & $\mathrm{Y}$ & $\mathrm{Y}$ \\
\hline Rainwater Harvesting & NA & $>5$ & $H / L$ & $\mathrm{Y}$ & 2 & $\mathrm{Y}$ & $\mathrm{Y}$ & $\mathrm{N}$ & $\mathrm{Y}$ & $\mathrm{N}$ & $\mathrm{N}$ & $\mathrm{Y}$ & $\mathrm{Y}$ \\
\hline Pervious Pavement & $\mathrm{N}$ & 5 & $H / L$ & $\mathrm{~N}$ & $>2$ & $\mathrm{Y}$ & $\mathrm{Y}$ & $\mathrm{N}$ & $\mathrm{Y}$ & $\mathrm{Y}$ & $\mathrm{N}$ & $\mathrm{Y}$ & Y \\
\hline Infiltration Trench & $\mathrm{N}$ & $>5$ & H & $\mathrm{N}$ & 2 & $\mathrm{Y}$ & $\mathrm{Y}$ & $\mathrm{Y}$ & $\mathrm{Y}$ & $\mathrm{N}$ & $\mathrm{N}$ & $\mathrm{Y}$ & $\mathrm{Y}$ \\
\hline Infiltration Basin & Y & $>5$ & $\mathrm{H}$ & $\mathrm{N}$ & $>2$ & $\mathrm{Y}$ & $\mathrm{Y}$ & $\mathrm{Y}$ & $\mathrm{Y}$ & $\mathrm{N}$ & $\mathrm{N}$ & $\mathrm{Y}$ & $\mathrm{Y}$ \\
\hline Soakaway & $\mathrm{N}$ & $>5$ & $\mathrm{H}$ & $\mathrm{N}$ & 2 & $\mathrm{Y}$ & $\mathrm{Y}$ & $\mathrm{Y}$ & $\mathrm{Y}$ & $\mathrm{N}$ & $\mathrm{N}$ & $\mathrm{Y}$ & $\mathrm{Y}$ \\
\hline Surface Sand Filter & Y & 5 & $\mathrm{H} / \mathrm{L}$ & $\mathrm{N}$ & $>2$ & $\mathrm{~N}$ & $\mathrm{Y}$ & $\mathrm{Y}$ & $\mathrm{Y}$ & $\mathrm{Y}$ & $\mathrm{N}$ & $\mathrm{Y}$ & $\mathrm{Y}$ \\
\hline Sub-surface Sand Filter & $\mathrm{N}$ & 5 & $\mathrm{H} / \mathrm{L}$ & $\mathrm{N}$ & 2 & $\mathrm{~N}$ & $\mathrm{Y}$ & $\mathrm{Y}$ & $\mathrm{Y}$ & $\mathrm{Y}$ & $\mathrm{N}$ & $\mathrm{Y}$ & $\mathrm{Y}$ \\
\hline Perimeter Sand Filter & $\mathrm{N}$ & 5 & $\mathrm{H} / \mathrm{L}$ & $\mathrm{N}$ & 2 & N & $\mathrm{N}$ & $\mathrm{Y}$ & $\mathrm{Y}$ & $Y$ & $\mathrm{~N}$ & $\mathrm{Y}$ & $\mathrm{Y}$ \\
\hline Bioretention/Filter Strips & Y & 5 & $\mathrm{H} / \mathrm{L}$ & $\mathrm{N}$ & 2 & $\mathrm{Y}$ & $\mathrm{Y}$ & $\mathrm{Y}$ & $\mathrm{Y}$ & $\mathrm{Y}$ & $\mathrm{N}$ & $\mathrm{Y}$ & $\mathrm{Y}$ \\
\hline Filter Trench & $\mathrm{N}$ & 5 & $H / L$ & $\mathrm{~N}$ & 2 & Y & $\mathrm{Y}$ & Y & $\mathrm{Y}$ & $\mathrm{Y}$ & $\mathrm{N}$ & $\mathrm{Y}$ & $\mathrm{Y}$ \\
\hline Conveyance Swale & $\mathrm{Y}$ & 5 & $H / L$ & $\mathrm{~N}$ & 2 & $\mathrm{Y}$ & $\mathrm{Y}$ & $\mathrm{Y}$ & $\mathrm{Y}$ & $\mathrm{Y}$ & Y & $\mathrm{Y}$ & $\mathrm{Y}$ \\
\hline Enhanced Dry Swale & Y & 5 & $H / L$ & $\mathrm{~N}$ & 2 & $\mathrm{Y}$ & $\mathrm{Y}$ & $\mathrm{Y}$ & $\mathrm{Y}$ & $\mathrm{Y}$ & Y & $\mathrm{Y}$ & $\mathrm{Y}$ \\
\hline Enhanced Wet Swale & Y & 5 & $\mathrm{H} / \mathrm{L}$ & $\mathrm{Y}$ & 2 & $Y$ & $\mathrm{Y}$ & $\mathrm{Y}$ & $\mathrm{Y}$ & $\mathrm{Y}$ & Y & $\mathrm{Y}$ & Y \\
\hline Detention Basin & Y & $>5$ & $H / L$ & $\mathrm{~N}$ & $>2$ & $\mathrm{Y}$ & $\mathrm{Y}$ & $\mathrm{Y}$ & $\mathrm{Y}$ & $\mathrm{Y}$ & Y & $\mathrm{Y}$ & $\mathrm{Y}$ \\
\hline Retention Pond & $\mathrm{Y}$ & $>5$ & $H / L$ & $\mathrm{Y}$ & $>2$ & $\mathrm{Y}$ & $\mathrm{Y}$ & $\mathrm{Y}$ & $\mathrm{Y}$ & $\mathrm{Y}$ & $\mathrm{Y}$ & $\mathrm{Y}$ & $\mathrm{Y}$ \\
\hline Subsurface Storage & $\mathrm{N}$ & $>5$ & $H / L$ & $\mathrm{Y}$ & $>2$ & $\mathrm{Y}$ & $\mathrm{Y}$ & $\mathrm{Y}$ & $\mathrm{Y}$ & $\mathrm{Y}$ & Y & $\mathrm{Y}$ & $\mathrm{Y}$ \\
\hline Shallow Wetland & $\mathrm{Y}$ & 5 & $H / L$ & $\mathrm{Y}$ & $>2$ & $\mathrm{Y}$ & $\mathrm{Y}$ & $\mathrm{Y}$ & $\mathrm{Y}$ & $\mathrm{Y}$ & $\mathrm{N}$ & $\mathrm{Y}$ & $\mathrm{Y}$ \\
\hline Extended Detention Wetland & $\mathrm{Y}$ & 5 & $H / L$ & $\mathrm{Y}$ & $>2$ & $\mathrm{Y}$ & $\mathrm{Y}$ & Y & $\mathrm{Y}$ & $\mathrm{Y}$ & $\mathrm{N}$ & $\mathrm{Y}$ & $\mathrm{Y}$ \\
\hline Pond/Wetland & $\mathrm{Y}$ & 5 & $\mathrm{H} / \mathrm{L}$ & $\mathrm{Y}$ & $>2$ & $\mathrm{Y}$ & $\mathrm{Y}$ & $\mathrm{Y}$ & $\mathrm{Y}$ & $\mathrm{Y}$ & $\mathrm{N}$ & $\mathrm{Y}$ & $\mathrm{Y}$ \\
\hline Pocket Wetland & $\mathrm{N}$ & 5 & $\mathrm{H} / \mathrm{L}$ & $\mathrm{Y}$ & 2 & $\mathrm{Y}$ & $\mathrm{Y}$ & $\mathrm{Y}$ & $\mathrm{Y}$ & $Y$ & $\mathrm{~N}$ & $\mathrm{Y}$ & $\mathrm{Y}$ \\
\hline Submerged Gravel Wetland & $Y$ & 5 & $\mathrm{H} / \mathrm{L}$ & $\mathrm{Y}$ & $>2$ & $\mathrm{Y}$ & $\mathrm{Y}$ & $\mathrm{Y}$ & $Y$ & $\mathrm{Y}$ & $\mathrm{N}$ & $\mathrm{Y}$ & $\mathrm{Y}$ \\
\hline Wetland Channel & $\mathrm{Y}$ & 5 & $H / L$ & $\mathrm{Y}$ & $>2$ & $\mathrm{Y}$ & $\mathrm{Y}$ & $\mathrm{Y}$ & $\mathrm{Y}$ & $\mathrm{Y}$ & $\mathrm{N}$ & $\mathrm{Y}$ & $\mathrm{Y}$ \\
\hline
\end{tabular}

Table 2 : Operations \& Maintenance Matrix 
Tables 4 and 5 for application to sites).

\begin{tabular}{|c|c|c|c|c|c|c|c|c|c|c|c|c|}
\hline \multirow[b]{2}{*}{ SUDS Technique } & \multicolumn{5}{|c|}{ Regular Maintenance (0.5) } & \multirow[b]{2}{*}{ 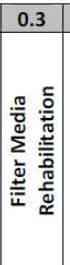 } & \multicolumn{6}{|c|}{ Occasional Maintenance $(\mathbf{0 . 2})$} \\
\hline & 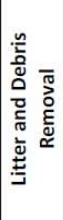 & 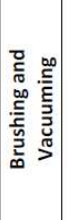 & 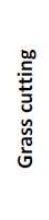 & 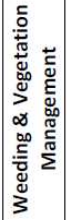 & 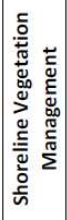 & & 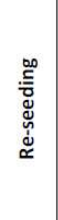 & 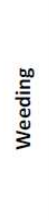 & 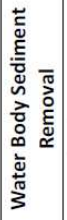 & 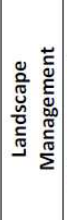 & 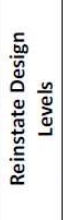 & 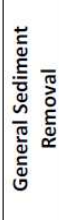 \\
\hline Green Roof & 2 & - & 2 & 2 & - & - & - & - & - & - & - & - \\
\hline Rainwater Harvesting & 1 & - & - & - & - & 3 & - & - & - & - & - & - \\
\hline Pervious Pavement & - & 1 & - & - & - & - & - & 1 & - & - & - & - \\
\hline Infiltration Trench & 1 & - & - & 1 & - & 1 & - & 1 & - & - & - & 1 \\
\hline Infiltration Basin & 1 & - & 1 & 1 & 1 & - & 1 & - & 1 & 1 & 1 & - \\
\hline Soakaway & 1 & - & - & 1 & - & - & - & - & - & - & - & - \\
\hline Surface Sand Filter & 4 & - & 4 & 3 & - & 2 & - & - & - & - & - & 1 \\
\hline Sub-surface Sand Filter & 4 & - & 4 & 3 & - & 2 & - & - & - & - & - & 1 \\
\hline Perimeter Sand Filter & 4 & - & 4 & 3 & - & 2 & - & - & - & - & - & 1 \\
\hline Bioretention/Filter Strips & $4 / 4$ & - & -13 & $1 / 2$ & - & - & $1 /-$ & $1 / 1$ & - & $1 /-$ & - & - \\
\hline Filter Trench & 4 & - & 2 & 3 & - & 2 & - & - & - & - & - & 2 \\
\hline Conveyance Swale & 4 & - & 3 & 2 & - & - & 1 & - & - & 1 & - & - \\
\hline Enhanced Dry Swale & 4 & - & 3 & 2 & - & - & 1 & - & - & 1 & - & 1 \\
\hline Enhanced Wet Swale & 4 & - & 3 & 2 & - & - & 1 & - & - & 1 & - & - \\
\hline Detention Basin & 4 & - & 2 & 2 & 1 & - & 1 & - & - & 1 & - & 1 \\
\hline Retention Pond & 1 & - & 1 & 1 & 1 & - & 1 & - & 1 & 1 & - & 1 \\
\hline Subsurface Storage & 3 & - & - & - & - & - & - & - & - & - & - & 1 \\
\hline Shallow Wetland & 4 & - & 3 & 2 & 1 & - & 1 & - & 1 & - & - & 2 \\
\hline Extended Detention Wetland & 1 & - & 1 & 1 & 1 & - & 1 & - & 1 & - & - & 1 \\
\hline Pond/Wetland & $1 / 1$ & - & $1 / 1$ & $1 / 1$ & $1 / 1$ & - & $1 / 1$ & - & $1 / 1$ & $1 /-$ & - & $1 / 1$ \\
\hline Pocket Wetland & 1 & - & 1 & 1 & 1 & - & 1 & - & 1 & - & - & 1 \\
\hline Submerged Gravel Wetland & 1 & - & 1 & 1 & 1 & - & 1 & - & 1 & - & - & 1 \\
\hline Wetland Channel & 1 & - & 1 & 1 & 1 & - & 1 & - & 1 & - & - & 1 \\
\hline $\begin{array}{r}\text { COMMENTS: } 1 \text { : Operation } \\
\text { O\&M score }=0\end{array}$ & $\Sigma(r$ & g. $m$ & & $\begin{array}{l}\text { 2: Oper } \\
\text { 4: Oper } \\
0.3 \times 1 \mathrm{f}\end{array}$ & $\begin{array}{l}\text { ration } \mathrm{H} \\
\text { ation } \mathrm{N} \\
\text { filter } \mathrm{r}\end{array}$ & ehab.) & 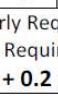 & $\begin{array}{l}\text { uired } \\
\text { ed } \\
\Sigma \text { (c }\end{array}$ & 3: Ope & naint) & ore & $\operatorname{an}$ \\
\hline
\end{tabular}

\section{Evaluation of technical performance using modelling tools}

Although it is not within the remit of this paper to explain the computer modelling involved in the evaluation of proposed SUDS, it must be noted that allocating appropriate modelling tools may importantly improve the level of detail and results of the method, particularly as to simulate hydraulic/treatment processes and environmental conditions in the studied areas.

Note for Tables 1 to 3: Coloured cells show the application of matrices for Site 1 (red cells indicate inadequate site characteristics for the technique).
Table 3: SUDS Performance Matrix.

\begin{tabular}{|c|c|c|c|c|c|c|c|c|c|}
\hline \multirow[b]{2}{*}{ SUDS Technique } & \multicolumn{6}{|c|}{ WATER QUALITY } & \multicolumn{3}{|c|}{ WATER QUANTITY } \\
\hline & 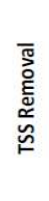 & 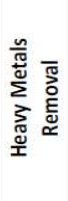 & 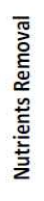 & 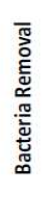 & 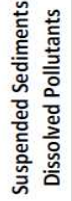 & 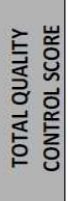 & 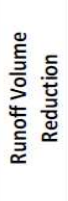 & 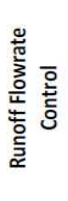 & 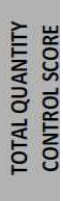 \\
\hline Green Roof & NA & NA & NA & NA & 3 & 3 & 3 & 3 & 6 \\
\hline Rainwater Harvesting & 2 & 1 & 1 & 1 & NA & 5 & 2 & 3 & 5 \\
\hline Pervious Pavement & 3 & 3 & 3 & 3 & 3 & 15 & 3 & 3 & 6 \\
\hline Infiltration Trench & 3 & 3 & 3 & 2 & 3 & 14 & 3 & 3 & 6 \\
\hline Infiltration Basin & 3 & 3 & 3 & 2 & 3 & 14 & 3 & 3 & 6 \\
\hline Soakaway & 3 & 3 & 3 & 2 & 3 & 14 & 3 & 3 & 6 \\
\hline Surface Sand Filter & 3 & 3 & 3 & 2 & 3 & 14 & 1 & 2 & 3 \\
\hline Sub-surface Sand Filter & 3 & 3 & 3 & 2 & 3 & 14 & 1 & 2 & 3 \\
\hline Perimeter Sand Filter & 3 & 3 & 3 & 2 & 3 & 14 & 1 & 2 & 3 \\
\hline Bioretention/Filter Strips & 3 & 3 & 3 & 2 & 3 & 14 & 1 & 2 & 3 \\
\hline Filter Trench & 3 & 3 & 3 & 2 & 3 & 14 & 1 & 3 & 4 \\
\hline Conveyance Swale & 3 & 2 & 2 & 2 & 3 & 12 & 2 & 3 & 5 \\
\hline Enhanced Dry Swale & 3 & 3 & 3 & 2 & 3 & 14 & 2 & 3 & 5 \\
\hline Enhanced Wet Swale & 3 & 3 & 2 & 3 & 3 & 14 & 1 & 3 & 4 \\
\hline Detention Basin & 2 & 2 & 1 & 1 & 1 & 7 & 1 & 3 & 4 \\
\hline Retention Pond & 3 & 2 & 2 & 2 & 3 & 12 & 1 & 3 & 4 \\
\hline Subsurface Storage & 1 & 1 & 1 & 1 & 1 & 5 & 1 & 3 & 4 \\
\hline Shallow Wetland & 3 & 2 & 3 & 2 & 3 & 13 & 1 & 2 & 3 \\
\hline Extended Detention Wetland & 3 & 2 & 3 & 2 & 3 & 13 & 1 & 2 & 3 \\
\hline Pond/Wetland & 3 & 2 & 3 & 2 & 3 & 13 & 1 & 2 & 3 \\
\hline Pocket Wetland & 3 & 2 & 3 & 2 & 3 & 13 & 1 & 2 & 3 \\
\hline Submerged Gravel Wetland & 3 & 2 & 3 & 2 & 3 & 13 & 1 & 2 & 3 \\
\hline Wetland Channel & 3 & 2 & 3 & 2 & 3 & 13 & 1 & 2 & 3 \\
\hline
\end{tabular}

\section{Evaluation of sustainability}


Selected SUDS were assessed in terms of technical, environmental, social and economic performance. In this sense, environmental, educational and community gain were prioritised in order to establish acceptable levels of sustainability. Should any of the solutions does not deliver satisfactory results, the method would resolve by either modifying the objectives for a particular site to acceptable limits within which the solution is acceptable, or restarting the methodology in order to consider discarded options or review applied criteria.

\section{DESCRIPTION OF STUDY AREAS}

Xàtiva and Benaguasil are two typical Spanish towns in terms of drainage conditions characterised by large impervious areas. Both towns suffer from seasonal flooding due to torrential rainfall events that overwhelm the capacity of combined sewers, thus resulting in uncontrolled spills discharged into local watercourses. These intense storms are normally caused by the 'gota fría' phenomenon, which brings large amounts of rainfall in a short period of time and accounts for an important share of the annual precipitations. Nevertheless, unlike Xàtiva, permeable soils in Benaguasil favour the implementation of a variety of different solutions for the same problems.

Political actors within City Councils have a major influence in the urban planning decisionmaking of Spanish towns. This fact strongly affects the final outcome of drainage projects and proposals, often resulting in biased processes where other interested parties (citizens, social organisations, etc) are hindered to participate. This is particularly disadvantageous when planning for SUDS, for a high level of stakeholder engagement is required.

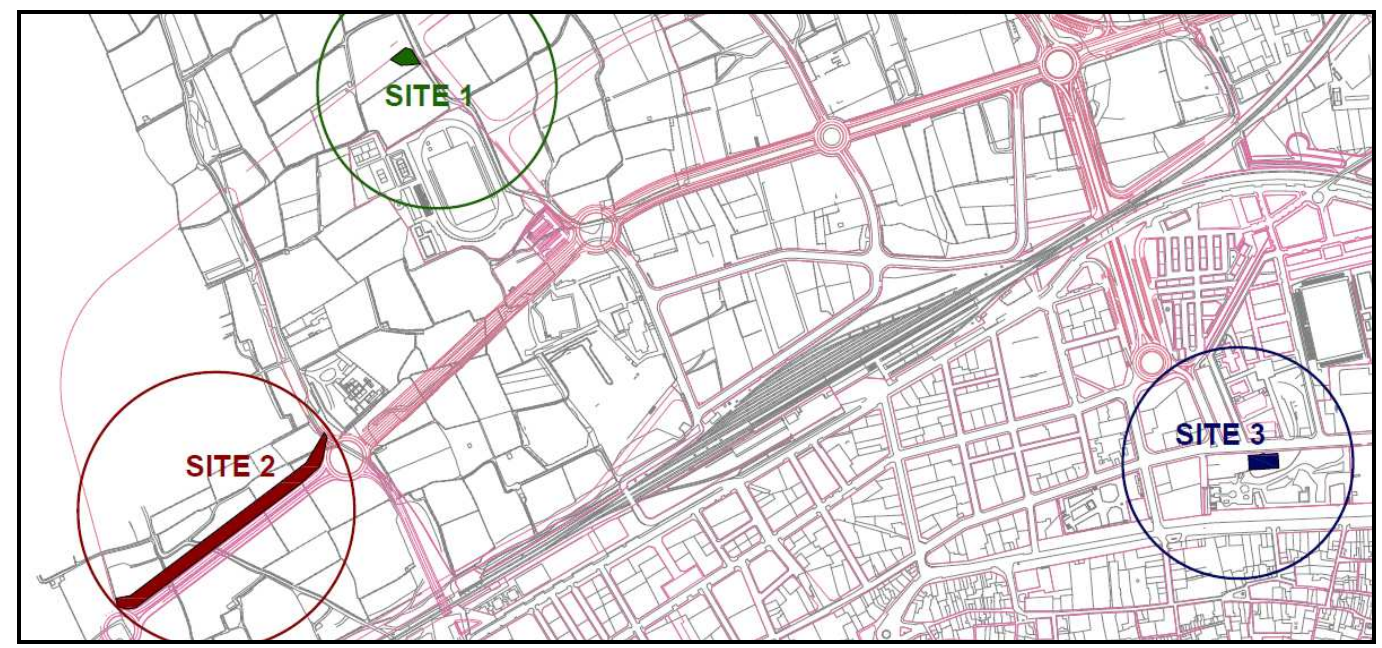

Figure 2. Sites Selected for SUDS in Xàtiva.

\section{XÀTIVA CASE STUDY}

Two categories of showcase sites were selected for the implementation of example SUDS in Xàtiva: developing areas in the boundaries of the town where drainage is required and available space permits to plan for SUDS (Sites 1 and 2 in Figure 2); and constrained urban areas where runoff can potentially be reduced and rainwater stored for subsequent use (Site 3). Proposed and selected SUDS for these sites are presented in Table 4. Since catchment areas at Site 2 mainly consisted of roads, the quality criteria (see Table 3) applied to the site were exclusively those concerning TSS and heavy metals, being primary pollutants for this type of urban surface. Similarly, the quality performance of the rooftop at Site 3 considered solely suspended solids and dissolved pollutants. 
The main purpose of Sites 1 and 2 is to delay the discharge of runoff into the main sewer; thus alleviating drainage problems due to CSO spills and surcharging manholes. Site 1 is a site lacking of appropriate drainage nearby a new local sports hall and a recreational area. The drainage area mainly involves a network of local roads and streets of low density development; however, the availability of space here is an issue.

Table 4. Proposed SUDS options for Xàtiva. Numbers in brackets indicate ranking in the group for each matrix criteria. Added rankings are presented in the global score column. (+) Preferred technique(s) for each site based on minimum global score. Techniques selected are highlighted in bold.

\begin{tabular}{|c|c|c|c|c|}
\hline & $\begin{array}{c}\text { Site Characteristics } \\
\text { Matrix \& } \\
\text { social/educational and } \\
\text { stakeholder's preferences }\end{array}$ & O\&M Matrix Score & $\begin{array}{c}\text { Technical } \\
\text { Performance Matrix } \\
\text { Score }\end{array}$ & $\begin{array}{l}\text { Global Score } \\
\text { (minimum score is } \\
\text { preferred technique) }\end{array}$ \\
\hline \multirow{2}{*}{ SITE 1} & Filter Trench (1) & $5.5(2)$ & $18(1)$ & $4(+)$ \\
\hline & Subsurface Storage (2) & $1.7(1)$ & $9(2)$ & 5 \\
\hline \multirow{4}{*}{ SITE 2} & Dry Swales (1) & $5.1(2)$ & $11(1)$ & $4(+)$ \\
\hline & Subsurface Storage (2) & $1.7(1)$ & $6(4)$ & 7 \\
\hline & Sand Filters (3) & $6.3(4)$ & $9(3)$ & 10 \\
\hline & Filter Trenches (4) & $5.5(3)$ & $10(2)$ & 9 \\
\hline \multirow{3}{*}{ SITE 3} & Greenroof (1) & $3(3)$ & $9(1)$ & $5(+)$ \\
\hline & Rainwater Harvest (2) & $1.4(1)$ & $5(2)$ & $5(+)$ \\
\hline & Subsurface Storage (3) & $1.7(2)$ & $5(2)$ & 7 \\
\hline
\end{tabular}

Site 2 is a stripe of land lying between the local motorway and a future residential development, both lacking appropriate drainage; and where green spaces, car-park bays and pavements will be soon constructed. Site 3 is the roof of a primary school located in a green area of the town centre. The selected SUDS for these sites were generally the preferred techniques of the method (see Table 4). Site 1 incorporates sub-surface storage to the filter trench as to reduce discharged volumes into the sewer and re-use runoff in adjacent fields. Site 2 is appropriate for a dry swale 'adaptable' to the future development layout. Finally, a combination of green roof and rainwater harvesting for Site 3 would allow for rainfall storage for non-potable uses.

\section{BENAGUASIL CASE STUDY}

Sites selected in Benaguasil belong to two main different categories: elevated town areas (Sites 4 and 6) where runoff accumulates and causes flooding problems downhill; and central areas where runoff might be reduced and rainwater stored for subsequent use (Site 5). Site 4 is a medium-sized park with a large drainage area ( $>2$ ha.). The SUDS is expected to reduce the volume of runoff flowing towards lower lying areas by means of infiltration. The surrounding land in Site 5 is completely paved with an adjacent garden placed in a lower area. Site 6 is intended as a showcase area to reduce the runoff generation from commercial facilities which are almost 100\% impervious surfaces, particularly rooftops and roads.

Infiltration basins and pervious pavement were suggested for Site 4 (see Table 5). However, potentially high sediment concentrations dictate against pervious pavements that risk rapid clogging. Further, infiltration basins were better fitted to the existing park area.

Table 5. Proposed SUDS options for Benaguasil. For explanation notes see Table 4. 


\begin{tabular}{|c|c|c|c|c|}
\hline & $\begin{array}{c}\text { Matrix \& } \\
\text { social/educational and } \\
\text { stakeholder's preferences } \\
\end{array}$ & & Performance Score & \\
\hline \multirow{4}{*}{ SITE 4} & Infiltration Basin (1) & $2.8(3)$ & $20(2)$ & $6(+)$ \\
\hline & Detention Basin (2) & $5.1(4)$ & $11(3)$ & 9 \\
\hline & Subsurface Storage (3) & $1.7(2)$ & $9(4)$ & 9 \\
\hline & Pervious Pavement (4) & $0.7(1)$ & $21(1)$ & $6(+)$ \\
\hline \multirow{5}{*}{ SITE 5} & Rainwater Harvest (1) & $1.4(2)$ & $10(4)$ & $7(+)$ \\
\hline & Subsurface Storage (2) & $1.7(3)$ & $9(5)$ & 10 \\
\hline & Sand Filters (3) & $6.3(5)$ & $17(3)$ & 11 \\
\hline & Filter Trench (4) & $5.5(4)$ & $18(2)$ & 10 \\
\hline & Pervious Pavement (5) & $0.7(1)$ & $21(1)$ & $7(+)$ \\
\hline \multirow{8}{*}{ SITE 6} & Infiltration Basin (1) & $2.8(5)$ & $20(2)$ & $8(+)$ \\
\hline & Bioretention (2) & $3.1(6)$ & $17(4)$ & 12 \\
\hline & Infiltration Trench (3) & $5.5(7)$ & $18(3)$ & 13 \\
\hline & Filter Trench (4) & $5.5(7)$ & $18(3)$ & 14 \\
\hline & Rainwater Harvest (5) & $1.4(3)$ & $10(5)$ & 13 \\
\hline & Subsurface Storage (6) & $1.7(4)$ & $9(6)$ & 16 \\
\hline & Soakaway (7) & $1(2)$ & $20(2)$ & 11 \\
\hline & Pervious Pavement (8) & $0.7(1)$ & $21(1)$ & 10 \\
\hline
\end{tabular}

Infiltration options such as infiltration basins, infiltration trenches and soakaways were discarded for Site 5 since it was intended to re-use the rainwater for watering a garden area and the relative insignificance of collected volumes for groundwater recharge. Pervious pavements were positively ranked but dismissed due to the amount of re-surfacing required. Instead, disconnection using rainwater collection and sub-surface storage was selected. Detention techniques such as swales and detention basins were also not considered for Site 6 , since infiltration options were preferred.

\section{SUSTAINABILITY OF SOLUTIONS}

From a technical point of view the solutions selected for Xàtiva are sound as they can store/ attenuate a reasonable amount of runoff, whilst having an important potential for removing urban pollutants. Consequently, the proposed solutions will significantly increase the drainage capacity of the sites under present and future climate scenarios (i.e. increased occurrence and intensity of precipitation). Indeed, reducing the rate, volume or pollutant concentration of those effluents potentially discharged into watercourses and sewers will both reduce the overall environmental impacts and reduce the energy requirements of the local WWTW through less volume to treat and less frequent uncontrolled spills.

The implementation, operation and maintenance costs of the in-ground systems are expected to be low. However, they are potentially at risk from clogging, and inspection of filter trenches may be difficult. Green roofs will also require additional building costs, although this may be largely outweighed by the benefits of improved insulation (e.g. reduced energy use in cooling systems during the summer) and noise absorption.

In contrast to Xàtiva, the options for Benaguasil are based on infiltration and water storage techniques that are expected to reduce system problems (e.g. CSO spills) whilst providing a source of aquifer/river recharge and, at smaller scale, water re-use (e.g. watering). Extra system capacity will be achieved without the need to enlarge sewer pipes, which will be particularly advantageous when considering future climatic conditions which may 
compromise the reliability of the entire drainage system. The river ecology will benefit and local water resources would be enhanced if they were widely implemented in the area, positively impacting those local activities which rely on water availability (e.g. agriculture).

The simplicity of the proposed SUDS makes them cost-effective solutions which are easy to construct, maintain and adapt to new conditions with very low investment requirements. Nevertheless, infiltration basins must be intensively monitored to ensure there is adequate pre-treatment and sediment levels are controlled.

Since this is and EU LIFE+ project, a further objective in both towns is to maximise the educational value and community benefits of the solutions in order to increase public acceptability and involvement of stakeholders in present and future decisions. These are, in general, visually appealing techniques that improve the aesthetics and social amenity of sites. Similarly, the use of eye-catching solutions in institutional and public facilities (school rooftop, sports hall) maximises their social and communicational impact. Good practice for commercial/light industry areas such as those in Benaguasil, may also be a step forward in developing municipal drainage/planning regulations that promote sustainability.

\section{LIMITATIONS AND NEED FOR FUTURE IMPROVEMENT}

A number of limitations to the procedure used were identified. The SUDS performance matrix was developed on the basis of UK experiences. There is a real need for local data regarding SUDS performance. Sustainability assessments should cover economic aspects (e.g. life-cycle analysis, affordability in the long term). A scoring system might be introduced to measure the effect of socio-economic factors. Consistent and comprehensive computer models should be developed to assist in the technical aspects of the selection process. The level and diversity of stakeholder engagement in the decision-making process is an issue and community and institutional engagement should replace intense political influence.

\section{CONCLUSIONS}

CSO spills pose particular problems for the successful implementation of European Drainage Directives in urban areas. In Spain, unlike other EU countries, the situation has generally worsened in recent decades by continued use of drainage approaches with only limited monitoring and evaluation of its immediate effects (i.e. flooding and pollution from CSO spills). Thus, improving urban drainage systems in Spain will require two tasks:

(1) Monitoring and analysis of current and future conditions; and

(2) Development of new alternatives that complement the traditional approach.

In order to address both objectives there is a need to create showcases to demonstrate the feasibility and suitability of new solutions in the long term. This is the purpose and motivation of the AQUAVAL project in the Region of Valencia.

The application of a SUDS methodology in a variety of common urban sites in this Region showed that potential technical improvement, social gain and environmental enhancement are all possible. The SUDS approach will address the effects of current and future extreme rain events through the implementation of source control and infiltration systems which consequently increase the resilience of the drainage system in the towns.

Finally, the paper shows the use of modified operation and maintenance scores for SUDS which intended to account for Mediterranean climatic conditions and may encourage discussion and subsequent improvement. In this sense, future examples of sustainable 
drainage using this type of decision-support framework will help understanding of the key criteria affecting the development of future drainage solutions in the Mediterranean region.

\section{REFERENCES}

Ayuntamiento de Madrid (2009). Buenas Prácticas en Arquitectura y Urbanismo para Madrid. Criterios Bioclimáticos y de Eficencia Energética. Madrid: Ayuntamiento de Madrid.

Castro-Fresno D., Rodríguez-Hernández J., Rodríguez-Bayón J. and Ballester-Muñoz F (2005). Sistemas urbanos de drenaje sostenible (SUDS). Interciencia. Volume 30, No. 5, pp. 255-260.

Castro-Fresno D., Rodríguez-Hernández J., Fernández-Barrera A.H. and Calzada-Pérez M.A. (2009). Runoff pollution treatment using an up-flow equipment with limestone and geotextil filtration media. WSEAS Transactions on Environmental and Development, Volume 5, Issue 4, pp. 341-350.

CIRIA (2007). The SUDS Manual, CIRIA C697. London: Construction Industry Research and Information Association.

Deutsch J. C., Revitt M., Ellis B. and Scholes L. (2003). Review of the Use of Stormwater BMPs in Europe. DAYWATER, Report 5.1.

Lau J., Butler D. and Schütze M. (2002). Is Combined Sewer Overflow Spill Frequency/Volume a Good Indicator of Receiving Water Quality Impact? Urban Water, Vol. 4, Issue 2, pp. 181-189.

Ministerio de Medio Ambiente (2002). Asistencia técnica para la redacción de una experiencia piloto de medición y estudio de las descargas de sistemas unitarios (DSU) del alcantarillado a los medios receptores en tiempo de tormenta, en varios municipios españoles. Resumen de los trabajos realizados. Secretaría de Estado de Agua y Costas. Dirección General de Obras Hidráulicas y Calidad de las Aguas.

Puertas-Agudo J., Suárez-López J. and Anta-Álvarez J. (2008). Gestión de las Aguas Pluviales. Implicaciones en el Diseño de Sistemas de Saneamiento y Drenaje Urbano. CEDEX. Madrid: Ministerio de Fomento.

Zabel T., Milne I. and Mackay G. (2001). Approaches Adopted by the European Union and Selected Member States for the Control of Urban Pollution. Urban Water, Vol. 3, Issues 1-2. 